\title{
Nod factors improve the nitrogen content and rhizobial diversity of faba bean and alter soil dehydrogenase, protease, and acid phosphomonoesterase activities**
}

\author{
Anna Siczek $^{1 * \mathbb{D}, \text { Jerzy Wielbo }}{ }^{\mathbb{D}}$, Jerzy Lipiec ${ }^{1} \mathbb{D}$, Stanisław Kalembasa ${ }^{3}$, Dorota Kalembasa ${ }^{3}$, \\ Dominika Kidaj ${ }^{2}$, and Pawet Szarlip ${ }^{4}$ \\ ${ }^{1}$ Institute of Agrophysics, Polish Academy of Sciences, Doświadczalna 4, 20-290 Lublin, Poland \\ ${ }^{2}$ Department of Genetics and Microbiology, M. Curie-Skłodowska University, Akademicka 19, 20-033 Lublin, Poland \\ ${ }^{3}$ Siedlce University of Natural Sciences and Humanities, Konarskiego 2, 08-110 Siedlce, Poland \\ ${ }^{4}$ „SHIM-POL A.M. Borzymowski”, Lubomirskiego 5, 05-080 Izabelin, Poland
}

Received February 21, 2019; accepted July 08, 2019

\begin{abstract}
Nod factors produced by rhizobia are one of the most important signals involved in symbiotic associations involving legumes. A field trial was performed to assess the symbiotic activity, rhizosphere biological parameters, and plant biomass of faba bean (Vicia faba L.) treated with Nod factors. The soil was a Haplic Luvisol derived from loess. The faba bean seeds (cv. Granit) were soaked with an Nod factors solution $(260 \mathrm{nM})$ or water (control) and sown. At the flowering stage, the genetic diversity of rhizobia (based on PCR-RFLP profiles and the sequencing of the 16-23S rDNA and nodD gene), nitrogenase activity (acetylene reduction assay), and nodule biomass were evaluated. Nitrogen yield and plant biomass were determined at the flowering and maturity stages. Rhizosphere soil was examined during plant growth in relation to the activities of dehydrogenase, protease, urease, and acid phosphomonoesterase. The results indicated that the application of the Nod factors improved nitrogenase activity (by $74-80 \%$, depending on the parameter analysed) and increased the genetic diversity of rhizobia inhabiting root nodules, plant nitrogen content (by $16.8 \%$, at maturity), and seed protein yield (by $14.6 \%$ ). The rhizobial population became more heterogeneous under the influence of the Nod factors than it was for the control (12 and 7 specific genotypes, respectively). At the flowering stage, Nod factors enhanced dehydrogenase, protease, and acid phosphomonoesterase activities by 46,36 and $9 \%$, respectively. The results revealed the positive effect of Nod factors at reducing water deficiency effects during a growing season with a short-term rainfall deficit.
\end{abstract}

Keywords: legume, rhizobial diversity, root nodules, biological nitrogen fixation, soil enzymes

\footnotetext{
*Corresponding author e-mail: asiczek@ipan.lublin.pl

**This work was supported by the National Science Centre in Poland on the basis of decision no. DEC-2012/07/B/NZ9/02430 and by statutory research (2013-2016).
}

\section{INTRODUCTION}

Faba bean is grown worldwide in cropping systems as a grain and green-manure legume and is a protein source in food and feed. Among the legumes cultivated in the EU, faba bean occupies the third position with respect to crop production, while it lies in second place regarding the amount of $\mathrm{N}$ fixed. Faba bean exhibited the most significant $\mathrm{N}$ balance ( $\mathrm{N}$ fixed $-\mathrm{N}$ offtake) $(19.8 \mathrm{~kg}$ of $\mathrm{N}$ per tonne of grain production) among grain legumes cultivated in the EU (Baddeley et al., 2013). The integration of faba bean into cropping systems has revealed many potential advantages in terms of increasing yield and quality, reducing diseases and pests, and influencing soil microbial activity and functions (Köpke and Nemecek, 2010; Li et al., 2013; Wahbi et al., 2016). It was shown that the introduction of faba bean into crop rotation increases microbial populations (bacteria and fungi) and enzyme activities (dehydrogenase, phosphatase, arylsulfatase, $\beta$-glucosidase and arylamidase), and also increases the rate of carbon mineralization, as well as modifying microbial populations and the catabolic capability of soil microorganisms (Aschi et al., 2017; Lupwayi and Kennedy, 2007). Moreover, the use of faba bean in crop rotation positively affected mycorrhizal colonization, which improves plant nutrient and water uptake, and enhances drought tolerance (Wahbi et al., 2016). The beneficial effects of legume influence on soil microbial activity could be connected with

(C) 2020 Institute of Agrophysics, Polish Academy of Sciences 
the biochemical composition and quantity of crop residues, including the higher amounts of organic carbon and nitrogen content incorporated into the soil through legume residues, as compared with crop rotation without legumes.

Apart from nitrogen from the soil, legumes may also utilize nitrogen from the atmosphere in the process of symbiotic nitrogen fixation, which is carried out by Rhizobium (Anglade et al., 2015). Legume-rhizobium symbiosis is a major contributor to the global nitrogen cycle and has great economic and ecological importance. In this interaction, in response to host plant root exudates containing flavonoids, nodulation genes are activated in rhizobia for the synthesis and secretion of lipochitooligosaccharides (LCO), named Nod factors (NF) (Janczarek et al., 2015). NF were found to induce infection and nodule organogenesis processes (D’Haeze and Holsters, 2002; Kelly et al., 2018).

The genetic diversity of rhizobial populations may be very large, even in individual plants which could be infected by numerous strains differing at a genetic as well as on a phenotypic level (Wielbo et al., 2010), also there are some suggestions that such diversity has a beneficial effect on plant growth (Wielbo et al., 2011).

The external application of NF had an impact on plant development and growth. The beneficial effect of NF was observed with regards to legume germination, the photosynthesis rate, nodulation, and plant growth parameters (Khan et al., 2008; Kidaj et al., 2012; Podleśny et al., 2014). The effects of NF were noted in relation to nonlegume plants such as barley, rice, cotton, corn, canola and Arabidopsis thaliana (Prithiviraj et al., 2003; Miransari and Smith, 2009; Marks et al., 2015; Schwinghamer et al., 2016). The improvement in germination and the early growth of seedlings (plant biomass, leaf area, root length) may be attributable to the stimulation of cell cycle genes and the morphogenetic capacity of NF.

The beneficial effects of NF application on roots, plant physiology, growth, and yields were observed under some stressful conditions such as low $\mathrm{pH}$ and temperature as well as water and salt stress (Duzan et al., 2004; Prudent et al., 2016; Nandhini et al., 2017). The positive effects of NF on pea growth and symbiotic activity were noted in compacted soils (Siczek et al., 2013). In field conditions, NF generally improved nitrogenase activity and pea yield in relatively dry but not during wet growing seasons (Siczek et al., 2014).

The literature review showed that studies concerning the effects of Nod factors were restricted to some legume species such as soybean, red clover, pea, and vetch, whereas faba bean has not been investigated as yet. Therefore, we hypothesized that the application of NF on faba bean seeds would improve the symbiotic activity, the genetic diversity of rhizobia inside nodules, plant growth, and soil enzyme activity. The aim of this study was to evaluate the effects of Nod factors on nitrogenase activity, nitrogen yield, the genetic diversity of Rhizobium, plant biomass and the rhizosphere enzyme activity of field-grown faba bean.

\section{MATERIALS AND METHODS}

The study was conducted in Lublin, Poland $\left(51^{\circ} 15^{\prime} \mathrm{N}\right.$, $22^{\circ} 35^{\prime} \mathrm{E}$ ). The soil was classified as a Haplic Luvisol (FAO, 1998) derived from loess with clay, silt, and sand content in the $0-20 \mathrm{~cm}$ soil layer of $70 \mathrm{~g} \mathrm{~kg}^{-1}, 290 \mathrm{~g} \mathrm{~kg}^{-1}$, and $640 \mathrm{~g} \mathrm{~kg}^{-1}$, respectively. The experiment was set up in 2015 in a field that was mouldboard ploughed to a $20-\mathrm{cm}$ depth before plot establishment. The soil $\mathrm{pH}$ was $6.1\left(\mathrm{H}_{2} \mathrm{O}\right)$ and the organic carbon content was $8.97 \mathrm{~g} \mathrm{~kg}^{-1}$. The total $\mathrm{N}$ content was $0.75 \mathrm{~g} \mathrm{~kg}^{-1}$ (Kjeldahl method (1883)) and the available $\mathrm{K}, \mathrm{P}, \mathrm{Mg}$ contents were 153,114 , and $39 \mathrm{mg} \mathrm{kg}^{-1}$, respectively in the $0-20 \mathrm{~cm}$ soil layer. Faba bean (Vicia faba L.) (cv. Granit) seeds were soaked for $30 \mathrm{~min}$ with a $260 \mathrm{nM}$ solution of the Nod factors (NF, Nod factors) or water $(\mathrm{C}$, control) $(500 \mathrm{ml}$ of NF solution or distilled water was used per $1 \mathrm{~kg}$ of seeds) and planted thereafter. Before sowing, the faba bean seeds were inoculated with an inoculum of R. leguminosarum bv. viciae (Nitragina) produced by the Institute of Soil Science and Plant Cultivation (IUNG, Puławy, Poland). The plots $(2 \mathrm{~m} \times 3 \mathrm{~m})$ were randomly organized into three replicates.

The Nod factors were isolated from $R$. leguminosarum bv. viciae strain GR09. Flavonoids from faba bean seed exudates were added to induce the synthesis of the Nod factors. The surface-sterilized seeds of faba bean were germinated in water for 4 days and then the supernatant was extracted with ethyl acetate. The ethyl acetate was evaporated, and the resulting pellet was resolubilized in 95\% ethanol. In order to determine the flavonoids content, the ethanol extracts were dried and weighed. The approximate flavonoid concentration in seed exudate was calculated relative to the molecular weight of authentic flavone.

Logarithmic cultures of $R$. leguminosarum bv. viciae strain GR09 were induced with sterile faba bean seed exudate at a final concentration of $10 \mu \mathrm{M}$. After $48 \mathrm{~h}$ of incubation, the culture was extracted with 0.2 volume of n-butanol (Prithiviraj et al., 2003). The organic fraction was separated and dried under vacuum. The amount of Nod factors was determined by the conversion of the amino sugars to methyl glycosides and gas chromatography/mass spectrometry (GC/MS) analysis. The concentration of the Nod factors was estimated based on the assumption that a single molecule of Nod factor contains on average four residues of $\mathrm{N}$-acetylglucosamine (GlcNAc). The content of GlcNAc in the Nod factor preparation was $260 \mathrm{nM}$. The procedure for NF isolation was the same as that described in Siczek et al. (2013).

At the flowering stage (BBCH 65), nitrogenase activity was assessed based on an acetylene reduction assay $\left(\mathrm{C}_{2} \mathrm{H}_{2}\right)$. Ten plants, which were treated as replicates, were taken randomly from both the control and Nod factors treatments. Cleaned roots with attached nodules were placed in bottles (one plant per bottle) and $10 \%(\mathrm{v} / \mathrm{v})$ of the gas from the bottles was replaced with acetylene. After $30 \mathrm{~min}$ incubation, 
the gas samples from the bottles were analysed for ethylene concentration by gas chromatography using a Shimadzu GC14-B with FID (Flame Ionization Detector). Detailed information is provided in Siczek et al. (2013). The roots with nodules were collected from the $0-15 \mathrm{~cm}$ soil layer. The amount of ethylene $\left(\mu \mathrm{mol} \mathrm{h}{ }^{-1}\right)$ was converted to the dry weight of one nodule (specific nitrogenase activity) and individual nodule. The number and dry mass $\left(65^{\circ} \mathrm{C}, 24 \mathrm{~h}\right)$ of nodules were determined for each plant separately.

R. leguminosarum strains were isolated at the end of the flowering stage (BBCH 69). Root nodules were surface-sterilized, crushed and plated on TY medium (5 $\mathrm{g}$ Bacto trypton, $3 \mathrm{~g}$ yeast extract, and $1.3 \mathrm{~g} \mathrm{CaCl}_{2}$ per litre). Isolates were purified by the successive re-streaking of single colonies. The level of genetic diversity was determined based on the number of different PCR-RFLP profiles. Total DNA was isolated from the rhizobial cells, and the 16-23S rDNA fragment (primers FGPS1490 5'-TGCGGCTGGATCACCTCCTT-3' and FGPL132 5'-CC GGGTTTCCCCATTCGG-3') as well as the nodD gene (primers: NBA12 5'GGATSGCAATCATCTAYRGMRTGG-3' and NBF12 5'-GGATCRAAAGCATCCRCASTATGG-3') (Laguerre et al., 1996) were amplified. The PCR reaction was performed in the following conditions: initial denaturation at $95^{\circ} \mathrm{C}$ for $3 \mathrm{~min}$, denaturation at $94^{\circ} \mathrm{C}$ for $1 \mathrm{~min}, 35$ cycles: primer attachment at $55^{\circ} \mathrm{C}$ for $1 \mathrm{~min}$, elongation at $72^{\circ} \mathrm{C}$ for $2 \mathrm{~min}$, and final elongation at $72^{\circ} \mathrm{C}$ for $5 \mathrm{~min}$. The PCR products obtained were digested with enzymes $B s u$ RI, $M s p \mathrm{I}, B s p 131 \mathrm{I}$ (for one hour at $37^{\circ} \mathrm{C}$ ), and $\operatorname{Taq} \mathrm{I}$ (for one hour at $65^{\circ} \mathrm{C}$ ). The restriction profiles were analysed after the electrophoretic separation of amplicons in a $3 \%$ agarose gel $(100 \mathrm{~V}, 2.5 \mathrm{~h})$.

For 32 selected strains representing different PCRRFLP profiles, the sequencing of the 16-23S rDNA and nodD amplicons was carried out. In the RFLP analysis, all restriction fragments $>100$ bp were compared, named, and attributed to the analysed strains; this was followed by agglomerative clustering performed using Statistica software (StatSoft Inc., Tulsa, OK, USA, 1997). The sequence analysis of the 16-23S rDNA and nodD amplicons as well as phylogenetic tree construction was carried out with DNASTAR Lasergene software (DNASTAR, Inc., Madison, Wisconsin, USA) using a Clustal W algorithm.

Plant biomass was determined in three replicates at the flowering $(\mathrm{BBCH} 65)$ and maturity $(\mathrm{BBCH}$ 99) stages. The harvested area was $0.5 \mathrm{~m}^{2}$ and the plant material collected at the flowering stage was dried at $65^{\circ} \mathrm{C}$ for $24 \mathrm{~h}$. The nitrogen content was determined separately for the leaves, stems, flowers, roots, and nodules (at flowering) and in the stems, pods, roots, and seeds (at maturity) with the Kjeldahl method (1883) in three replications and afterwards the values were summarized separately for both stages. At both stages, faba bean roots were collected from the $0-15 \mathrm{~cm}$ soil layer. The seed protein yield was calculated based on the seed yield and the nitrogen content of the seeds.
Faba bean rhizosphere soil samples (the soil adhering tightly to the roots was collected by first shaking off the loosely adhering soil) from the $0-15 \mathrm{~cm}$ layer were taken three times during the vegetative period, at $\mathrm{T} 1$ corresponding to the 5-6 leaf stage (BBCH 15-16), T2 - flowering (BBCH 65 ), and $\mathrm{T} 3$ - development of the fruit (BBCH 79) of the faba bean. The number of days from sowing to harvest was 46, 61 and 102 for T1, T2 and T3, respectively. The soil used for enzymatic analyses was sieved through a $0.2 \mathrm{~cm}$ mesh.

Dehydrogenase activity was measured using the Thalmann method (1968) modified by Alef (1995), urease activity was assessed with the method developed by Zantua and Bremner (1977), and protease activity was determined with the method proposed by Ladd and Butler (1972) and modified by Alef and Nannipieri (1995). The Tabatabai and Bremner (1969) method was used for the determination of acid phosphomonoesterase activity. Each analysis was performed in four replicates. The results were converted into the dry $\left(105^{\circ} \mathrm{C}\right)$ weight of the soil.

Statistica 10.0 software (StatSoft Inc., Tulsa, OK, USA, 2011) was used to obtain the statistical analyses. A comparison of means was performed on the basis of analysis of variance (ANOVA) and post-hoc Tukey's HSD test at a $\mathrm{p}<0.05$ significance level.

\section{RESULTS}

The nodule number and dry weight did not change significantly $(p<0.05)$ after the application of the Nod factors (Table 1). However, the activity of the nodules increased greatly in NF compared to the control. Nitrogenase activity per one plant, per nodule dry weight, and per one nodule significantly exceeded the values observed in the control (by 80,77 , and $74 \%$, respectively).

Table 1. Parameters of nodules and nitrogenase activity as influenced by Nod factors application with standard deviations $(n=10)$. Different letters in rows indicate significant differences $(p<0.05)$

\begin{tabular}{lcc}
\hline \multicolumn{1}{c}{ Parameters } & Control & Nod factors \\
\hline & Nodules \\
Number $\left(\right.$ plant $\left.^{-1}\right)$ & $86.8(37.0) \mathrm{a}$ & $103.0(23.2) \mathrm{a}$ \\
Dry weight $\left(\mathrm{mg} \mathrm{plant}^{-1}\right)$ & $0.085(0.026) \mathrm{a}$ & $0.101(0.025) \mathrm{a}$ \\
\multicolumn{3}{c}{ Nitrogenase activity } \\
$\mathrm{C}_{2} \mathrm{H}_{4} \mu \mathrm{mol} \mathrm{h}^{-1}$ & $4.58(4.28) \mathrm{b}$ & $22.37(7.56) \mathrm{a}$ \\
$\mathrm{C}_{2} \mathrm{H}_{4} \mu \mathrm{mol} \mathrm{h}^{-1}$ g nodule $^{-1}$ & $51.7(44.2) \mathrm{b}$ & $220.3(48.7) \mathrm{a}$ \\
$\mathrm{C}_{2} \mathrm{H}_{4} \mathrm{nmol} \mathrm{h}^{-1}$ nodule $^{-1}$ & $56.1(50.9) \mathrm{b}$ & $221.1(74.8) \mathrm{a}$ \\
\hline
\end{tabular}

At the end of the flowering stage, the root nodules were collected, 42 strains were isolated and 12 genotypes were identified from the control, also 45 strains and 17 genotypes were identified from NF (Fig. 1). In total, 24 different genotypes were identified. In the control and NF, 5 common genotypes were present, however, two of them occurred more frequently than the specific genotypes (19-38\%). The NF population was more heterogeneous than the control (12 and 7 specific genotypes, respectively). A greater variation in the 


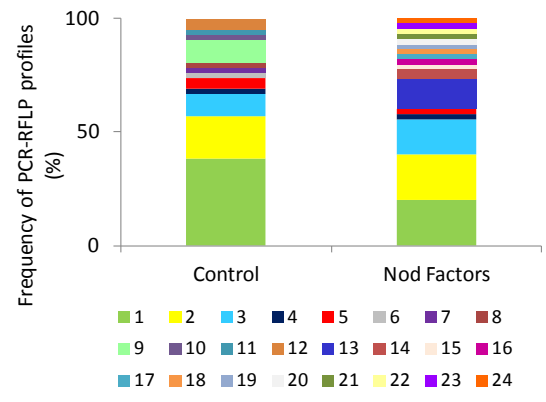

Fig. 1. The effect of Nod Factors on the frequency of different genotypes (1-24) based on PCR-RFLP of 16-23S rDNA and nodD gene profiles obtained in the faba bean nodules rhizobial isolates.
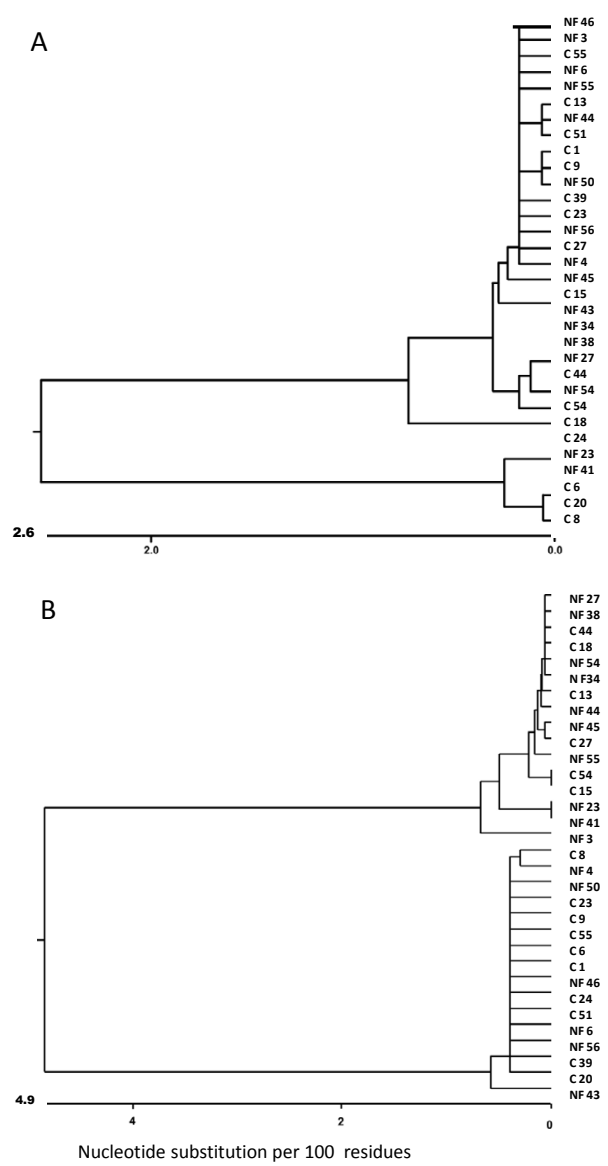

Fig. 2. Phylogenetic trees for 32 selected rhizobial strains from Control (C) and Nod Factors (NF) treatments for 16-23S rDNA (A) and nodD amplicons (B). R. leguminosarum strains were isolated at the end of the flowering stage from faba bean nodules. The sequence analysis of the 16-23S rDNA and nodD amplicons as well as the phylogenetic tree construction was carried out with DNASTAR Lasergene software using a Clustal W algorithm.
Table 2. Plant growth parameters of faba bean as influenced by Nod factors application with standard deviations $(n=3)$. Different letters in rows indicate significant differences $(p<0.05)$

\begin{tabular}{lcc}
\hline \multicolumn{1}{c}{ Plant parameters } & Control & Nod Factors \\
\hline & Flowering \\
Plant biomass $\left(\mathrm{g} \mathrm{m}^{-2}\right)$ & $617(40.4) \mathrm{a}$ & $699(32.6) \mathrm{a}$ \\
Total plant $\mathrm{N}\left(\mathrm{g} \mathrm{m}^{-2}\right)$ & $14.5(1.25) \mathrm{a}$ & $16.3(0.93) \mathrm{a}$ \\
& Maturity & \\
Plant biomass $\left(\mathrm{g} \mathrm{m}^{-2}\right)$ & $1057(53.2) \mathrm{a}$ & $1126(56.4) \mathrm{a}$ \\
Total plant $\mathrm{N}\left(\mathrm{g} \mathrm{m}^{-2}\right)$ & $24.1(0.70) \mathrm{b}$ & $28.2(2.05) \mathrm{a}$ \\
Seed protein yield $\left(\mathrm{g} \mathrm{m}^{-2}\right)$ & $120(6.3) \mathrm{b}$ & $137(5.9) \mathrm{a}$ \\
\hline
\end{tabular}

nodD gene sequence than that of the 16-23S rDNA sequence (maximum $>4$ and $>2$ substitutions $/ 100 \mathrm{bp}$, respectively) was noted. Most of the 16-23S rDNA region sequences were grouped within a cluster with an internal difference of less than 1 substitution/100 bp (Fig. 2A). The sequences of the nodD gene were grouped into two clusters (Fig. 2B) characterized by a slight internal variation; the sequences from the $\mathrm{NF}$ group strains were predominant within one cluster and those from group $\mathrm{C}$ dominated within the other.

Although higher in the NF than in the control, plant biomass did not differ significantly between the treatments at the flowering and maturity stages (Table 2 ). The $\mathrm{N}$ content in faba bean biomass at maturity and seed protein yield increased $(\mathrm{p}>0.05)$ by $16.8 \%$ and $14.6 \%$, respectively, after the seeds were treated with the Nod factors.

The effect of NF on soil enzymatic activity was beneficial $(\mathrm{p}<0.05)$ at the flowering stage with respect to dehydrogenase, protease and acid phosphomonoesterase (NF increased their activity by 46,36 and $9 \%$, respectively) (Table 3). Urease activity did not differ between treatments for all the growth stages.

\section{DISCUSSION}

In this study, the Nod factors improved soil biological parameters by increasing the activities of the enzymes involved in the $\mathrm{N}$ and $\mathrm{P}$ cycle (protease and acid phosphomonoesterase) and total activity (dehydrogenase). This enhancement of protease and acid phosphomonoesterase activities indicate respectively a high release of protein $\mathrm{N}$ (Paul and Clark, 1996; Schimel and Bennett, 2004) as well as inorganic phosphorus from organic phosphomonoesters (Alef et al., 1995). In turn, dehydrogenase plays a pivotal role in the oxidation of soil organic matter by hydrogen transfer from the organic substrate to inorganic acceptors (Zhang

Table 3. Soil enzyme activity as influenced by Nod factors application with standard deviations $(n=4)$. Different letters in columns indicate significant differences $(\mathrm{p}<0.05)$

\begin{tabular}{llcccc}
\hline \multicolumn{1}{c}{ Growth stage } & \multicolumn{1}{c}{ Treatment } & $\begin{array}{c}\text { Dehydrogenase } \\
\left(\mathrm{cm}^{3} \mathrm{H}_{2} \mathrm{~kg}^{-1} \mathrm{~d}^{-1}\right)\end{array}$ & $\begin{array}{c}\text { Protease } \\
\left(\mathrm{mg} \text { tyrosine } \mathrm{kg}^{-1} \mathrm{~h}^{-1}\right)\end{array}$ & $\begin{array}{c}\text { Urease } \\
\left(\mathrm{mg} \mathrm{kg}^{-1} \mathrm{~h}^{-1}\right)\end{array}$ & $\begin{array}{c}\text { Acid phosphomonoesterase } \\
\left(\mathrm{mg} \mathrm{PNP} \mathrm{kg}^{-1} \mathrm{~h}^{-1}\right)\end{array}$ \\
\hline 5-6 leaves & Control & $18.3(1.07) \mathrm{e}$ & $3.1(0.37) \mathrm{b}$ & $1.1(0.06) \mathrm{b}$ & $38.9(1.21) \mathrm{ab}$ \\
& Nod Factors & $17.1(0.82) \mathrm{e}$ & $3.8(1.00) \mathrm{b}$ & $1.4(0.04) \mathrm{ab}$ & $41.1(2.28) \mathrm{a}$ \\
Flowering & Control & $37.7(1.29) \mathrm{d}$ & $3.8(0.61) \mathrm{b}$ & $1.1(0.08) \mathrm{b}$ & $36.6(1.09) \mathrm{b}$ \\
& Nod Factors & $70.5(2.15) \mathrm{a}$ & $5.9(0.55) \mathrm{a}$ & $1.8(0.73) \mathrm{ab}$ & $40.3(1.71) \mathrm{a}$ \\
Development of fruit & $53.1(5.38) \mathrm{b}$ & $2.9(0.11) \mathrm{b}$ & $2.1(0.53) \mathrm{a}$ & $40.3(1.69) \mathrm{a}$ \\
& Control & $45.5(3.97) \mathrm{c}$ & $2.7(0.31) \mathrm{b}$ & $1.6(0.30) \mathrm{ab}$ & $40.4(0.98) \mathrm{a}$ \\
\hline
\end{tabular}


et al., 2010), thus the enhanced activity of this enzyme by NF may be connected with the higher rate of organic matter mineralization. The enhanced activities of the enzymes suggest an increase in nutrient availability to plants and microbes induced by the application of NF and thus may provide a favourable environment for faba bean growth. This beneficial effect was mainly observed at the flowering stage, which is one of the most critical stages for plant yield potential. Enhanced enzyme activity may be connected with the beneficial influence of NF on plant root growth (Kidaj et al., 2012; Podleśny et al., 2014; Marks et al., 2015).

The beneficial effect of NF on nodule activity was connected with the increased genetic diversity of the rhizobial strains inside the nodules of the NF-treated plants. This suggests that NF reduce the competitive pressure between the rhizobial strains and this increases the number of nodules which can be colonized by rhizobia. The competitiveness of $R$. leguminosarum strains is under the influence of different bacterial traits (Wielbo et al., 2007; Maj et al., 2010; Wielbo et al., 2012) and is not associated with symbiotic effectiveness. Nevertheless, it may be speculated that the increase in nodule number observed after Nod factors treatment allow for the infection of plants by strains with high symbiotic effectiveness and low competitiveness, and this is the reason for higher nitrogenase activity. The influence of NF on the genetic diversity of rhizobia colonizing pea and vetch nodules was previously observed by Kidaj et al. (2012) in a laboratory experiment. However, this beneficial effect on genetic diversity was observed to be greater in our study under field conditions.

The $\mathrm{N}$ content in plant biomass did not differ significantly between treatments at the flowering stage, however, at the maturity stage, it was significantly $(\mathrm{p}<0.05)$ improved by NF. This implies the long-term effect of NF. These results are supported by data obtained in a pot experiment by Podleśny et al. (2014), who noted the improved N content in pea plants after NF application. The beneficial effect of NF on plant growth could be partly due to its influence on the rhizospheric microbial community. As indicated by Siczek et al. (2015) NF significantly increased the Bacillus and Pseudomonas population. It has been shown that some species of these bacteria positively affected legume growth, yield and symbiotic activity (Zahir et al., 2011).

In a field experiment conducted with pea plants under the same climatic conditions (Siczek et al., 2014), the application of NF increased nitrogenase activity $(p<0.05)$ and plant growth in a relatively dry season, but this effect was not observed during the wet growing season. A similar conclusion may be drawn from the present study. With reference to the long-term average $(572 \mathrm{~mm}$ ) (Siczek et al., 2014), the yearly precipitation of 2015 was similar (531 $\mathrm{mm}$ ) as measured by the meteorological station close to the experimental field. However, the amount of rainfall during the faba bean growing season (April-August) was considerably lower in 2015 than the long-term average (by 39\%).
It was demonstrated previously, in a laboratory study by Prudent et al. (2016) that NF application under water stress conditions increased the amount of $\mathrm{N}$ fixed and nodule parameters over the control. This NF effect is connected with an increase in the content of cytokinins (Prudent et al., 2016), which are known to promote nodule organogenesis (Gamas et al., 2017) as well as lateral root formation (Kiba et al., 2011). Improved root growth due to NF, as indicated in earlier studies (Siczek et al., 2013; Podleśny et al., 2014) may result in improved water and nutrient absorption and thus the enhancement of nodule activity and $\mathrm{N}$ yield.

In the case of Nod factors there are several possible effects: the "primary effect" is an increase in the number of nodules due to the induction of more meristems. As Nod factors are signalling molecules, a change in their concentration in the environment probably interferes with the process of signal exchange between the rhizobia and plants, and therefore various "secondary effects" like the change in the composition of populations of rhizobia colonizing nodules are observed.

Similar results concerning the application of Nod factors for the improvement of plant productivity have been obtained for other legumes, such as soybean and pea (Smith et al., 2015). However, to date, there is no research data available in relation to the faba bean. The results suggest that the application of Nod factors may have a beneficial effect on faba bean symbiotic activity and productivity for the years with lower precipitation during the growing season. Such a response may also have a positive effect on future faba bean productivity in light of the progressive decrease in precipitation during the growing season in Poland (Denisow and Malinowski, 2016). Further studies are intended to assess these effects over the course of a long-term field experiment.

\section{CONCLUDING REMARKS}

This study has shown that the treatment of faba bean seeds with Nod factors (NF) influenced both symbiotic nitrogen fixation and the rhizobia population in nodules, soil microbial activity, and faba bean yields.

1. The application of Nod factors before sowing improved the nitrogenase activity and changed the genetic diversity of rhizobia inhabiting root nodules.

2. At the flowering stage, Nod factors increased dehydrogenase activity as well as the protease and phosphomonoesterase activity connected with the $\mathrm{N}$ and $\mathrm{P}$ cycles.

2. Nitrogen and seed protein yields were improved by $\mathrm{NF}$ in comparison with the control.

3. The results of this study demonstrate that the addition of Nod factors may exert a positive influence on faba bean growth during seasons with a short-term rainfall deficit by increasing the symbiotic nitrogen fixation efficiency and therefore, the nitrogen yield. 
Conflict of interest: The authors declare that they have no conflict of interest.

\section{REFERENCES}

Alef K., 1995. Dehydrogenase activity. In: Methods in applied soil microbiology and biochemistry (Eds K. Alef, P. Nannipieri). 228-231, London, Academic Press.

Alef K., Nannipieri P., and Trazar-Cepeda C., 1995. Phosphatase activity. In: Methods in applied soil microbiology and biochemistry (Eds K. Alef, P. Nannipieri). 335-344. London, Academic Press.

Alef K. and Nannipieri P., 1995. Protease activity. In: Methods in applied soil microbiology and biochemistry (Eds K. Alef, P. Nannipieri). 313-315, London, Academic Press.

Anglade J., Billen G., and Garnier J., 2015. Relationships for estimating $\mathrm{N}_{2}$ fixation in legumes: incidence for $\mathrm{N}$ balance of legume-based cropping systems in Europe. Ecosphere, 6(3), 37, http://dx.doi.org/10.1890/ES14-00353.1

Aschi A., Aubert M., Riah-Anglet W., Nélieu S., Dubois C., Akpa-Vinceslas M., and Trinsoutrot-Gattin I., 2017. Introduction of Faba bean in crop rotation: Impacts on soil chemical and biological characteristics. Appl. Soil Ecol., 120, 219-228, https://doi.org/10.1016/j.apsoil.2017.08.003

Baddeley J.A., Jones S., Topp C.F.E., Watson C.A., Helming J., and Stoddard F.L., 2013. Biological nitrogen fixation (BNF) in Europe. Legume Futures Report 1.5. Available from www.legumefutures.de

Denisow B. and Malinowski D.P., 2016. Climate change and the future of our world - implications for plant phenology, physiology, plant communities, and crop management. Acta Agrobot., 69(2), 1683. http://dx.doi.org/10.5586/aa.1683

D'Haeze W. and Holsters M., 2002. Nod factor structures, responses, and perception during initiation of nodule development. Glycobiology, 12, 79-105, https://doi.org/10.1093/ glycob/12.6.79R

Duzan H.M., Zhou X., Souleimanov A., and Smith, D.L., 2004. Perception of Bradyrhizobium japonicum Nod factor by soybean (Glycine max L. Merr.) root hairs under abiotic stress conditions. J. Exp. Bot., 55, 2641-2646, https://doi. org/10.1093/jxb/erh265

FAO, 1998. World Reference Base for Soil Resources. World Soil Resources Report 84. FAO, Rome. 88pp.

Gamas P., Brault M., Jardinaud M.F., and Frugier F., 2017. Cytokinins in Symbiotic Nodulation: When, Where, What For? Trends Plant Sci., 22, 792-802, https://doi.org/10.1016 /j.tplants.2017.06.012

Janczarek M., Rachwal K., Marzec A., Grządziel J., and Palusińska-Szysz M., 2015. Signal molecules and cell-surface components involved in early stages of the legume-rhizobium interactions. Appl. Soil Ecol., 85, 94-113, https://doi.org/10.1016/j.apsoil.2014.08.010

Kelly S., Sullivan J.T., Kawaharada Y., Radutoiu S., Ronson S.C., and Stougaar J., 2018. Regulation of Nod factor biosynthesis by alternative NodD proteins at distinct stages of symbiosis provides additional compatibility scrutiny. Environ. Microbiol., 20, 97-110, https://doi.org/10.1111/ 1462-2920.14006
Khan W., Prithiviraj B., and Smith D.L., 2008. Nod factor [Nod $\mathrm{Bj} \mathrm{V}(\mathrm{C} 18: 1, \mathrm{MeFuc})]$ and lumichrome enhance photosynthesis and growth of corn and soybean. J. Plant Physiol., 165, 1342-1351, https://doi.org/10.1016/j.jplph.2007.11.001

Kiba T., Kudo T., Kojima M., and Sakakibara H., 2011. Hormonal control of nitrogen acquisition: roles of auxin, abscisic acid, and cytokinin. J. Exp. Bot., 62, 1399-409, https://doi.org/10.1093/jxb/erq410

Kidaj D., Wielbo J., and Skorupska A., 2012. Nod factors stimulate seed germination and promote growth and nodulation of pea and vetch under competitive conditions. Microbiol. Res., 167, 144-150, https://doi.org/10.1016/j.micres.2011.06.001

Kjeldahl J.G., 1883. Neue Methode zur Bestimmung des Stickstoffs in organischen Körpern (New method for the determination of nitrogen in organic substances). Zeitschrift für analytische Chemie, 22, 366-383, https://doi.org/10.1007/ BF01338151

Köpke U. and Nemecek T., 2010. Ecological services of faba bean. Field Crops Res., 115, 217-233, https://doi.org/10.1016 /j.fcr.2009.10.012

Ladd J.N. and Butler J.H.A., 1972. Short-term assays of soil proteolytic enzyme activities using proteins and dipeptide derivatives as substrates. Soil Biol. Biochem., 4, 19-30, https://doi.org/10.1016/0038-0717(72)90038-7

Laguerre G., Mavingui P., Allard M.R., Charnay M.P., Louvrier P., Mazurier S.I., Rigottier-Gois L., and Amarger N., 1996. Typing of rhizobia by PCR DNA fingerprinting and PCR-restriction fragment length polymorphism analysis of chromosomal and symbiotic gene regions: application to Rhizobium leguminosarum and its different biovars. Appl. Environ. Microbiol., 62, 2029-2036.

Li H., Zhang F., Rengel Z., and Shen J., 2013. Rhizosphere properties in monocropping and intercropping systems between faba bean (Vicia faba L.) and maize (Zea mays L.) grown in a calcareous soil. Crop Pasture Sci., 64, 976-984, https://doi.org/10.1071/CP13268

Lupwayi N.Z., and Kennedy A.C., 2007. Grain legumes in Northern Great Plains: impacts on selected biological soil Processes. Agron. J., 99, 1700-1709, https://doi.org/10.2134/ agronj2006.0313s

Maj D., Wielbo J., Marek-Kozaczuk M., and Skorupska A., 2010. Response to flavonoids as a factor influencing competitiveness and symbiotic activity of Rhizobium leguminosarum. Microbiol. Res., 165, 50-60, https://doi. org/10.1016/j.micres.2008.06.002

Marks B.B., Megías M., Ollero F.J., Nogueira M.A., Araujo R.S., and Hungria M., 2015. Maize growth promotion by inoculation with Azospirillum brasilense and metabolites of Rhizobium tropici enriched on lipo-chitooligosaccharides (LCOs). AMB Express, 5, 71, https://doi.org/10.1186/ s13568-015-0154-Z

Miransari M. and Smith D., 2009. Rhizobial lipo-chitooligosaccharides and gibberellins enhance barley (Hordeum vulgare L.) seed germination. Biotechnology, 8, 270-275, https:// doi.org/10.3923/biotech.2009.270.275

Nandhini D.U., Somasundaram E., and Amanullah M.M., 2017. Effect of rhizobial nod factors (lipochitooligosaccharide) on seedling growth of blackgram under salt stress. Legume Res., 41, 159-162, https://doi.org/10.18805/LR-3597

Paul E.A., and Clark F.E., 1996. Soil Biology and Biochemistry, Academic Press: San Diego, CA, USA. 
Podleśny J., Wielbo J., Podleśna A., and Kidaj D., 2014. The pleiotropic effects of extract containing rhizobial Nod factors on pea growth and yield. Cent. Eur. J. Biol., 9, 396-409, https://doi.org/10.2478/s11535-013-0277-7

Prithiviraj B., Zhou X., Souleimanov A., Kahn W.M., and Smith D.L., 2003. A host-specific bacteria-to-plant signal molecule (Nod factor) enhances germination and early growth of diverse crop plants. Planta, 216, 437-445.

Prudent M., Salon C., Smith D.L., and Emery R.J.N., 2016. Nod factor supply under water stress conditions modulates cytokinin biosynthesis and enhances nodule formation and N nutrition in soybean. Plant Signal Behav., 11, e1212799, https://doi.org/10.1080/15592324.2016.1212799

Schimel J.P. and Bennett J., 2004. Nitrogen mineralization: Challenges of a changing paradigm. Ecology, 85, 591-602, https://doi.org/10.1890/03-8002

Schwinghamer T., Souleimanov A., Dutilleul P., and Smith D., 2016. Supplementation with solutions of lipo-chitooligosacharide Nod Bj V (C18:1, MeFuc) and thuricin 17 regulates leaf arrangement, biomass, and root development of canola (Brassica napus L.). Plant Growth Regul., 78, 31-41, https://doi.org/10.1007/s10725-015-0072-8

Siczek A., Frąc M., Nawrocka A., Wielbo J., and Kidaj D., 2015. The response of rhizosphere microbial properties to flavonoids and Nod factors. Acta Agric. Scand., Soil Plant Sci., 65, 125-131, https://doi.org/10.1080/09064710.2014.975835

Siczek A., Lipiec J., Wielbo J., Kidaj D., and Szarlip P., 2014. Symbiotic activity of pea (Pisum sativum) after application of nod factors under field conditions. Int. J. Mol. Sci., 15, 7344-7351, https://doi.org/10.3390/ijms15057344

Siczek A., Lipiec J., Wielbo J., Szarlip P., and Kidaj D., 2013. Pea growth and symbiotic activity response to Nod factors (lipochitooligosaccharides) and soil compaction. Appl. Soil Ecol., 72, 181-186, https://doi.org/10.1016/j.apsoil.2013.06.012

Smith S., Habib A., Kang Y., Leggett M., and Diaz-Zorita M., 2015. LCO applications provide improved responses with legumes and nonlegumes. In: Biological Nitrogen Fixation (Ed. F.J. de Bruijn). pp. 1077-1085. 1st edn. John Wiley \& Sons Inc, https://doi.org/10.1002/9781119053095.ch107

Tabatabai M.A. and Bremner J.M., 1969. Use of p-nitrophenyl phosphate for assay of soil phosphatase activity. Soil Biol. Biochem. 1, 301-307, https://doi.org/10.1016/0038-0717 (69)90012-1
Thalmann A., 1968. Zur Methodik der Bestimmung der Dehydrogenase - Aktivität im Boden mittels Triphenyltetrazoliumchlorid (TTC). Landwirtsh Forsch, 21, 249-258.

Wahbi S., Prin Y., Thioulouse J., Sanguin H., Baudoin E., Maghraoui T., Oufdou K., Le Roux C., Galiana A., Hafidi M., and Duponnois R., 2016. Impact of wheat/faba bean mixed cropping or rotation systems on soil microbial functionalities. Front. Plant Sci., 7, 1364, https://doi.org/ 10.3389/fpls.2016.01364

Wielbo J., Kidaj D., Koper P., Kubik-Komar A., and Skorupska A., 2012. The effect of biotic and physical factors on the competitive ability of Rhizobium leguminosarum. Cent. Eur. J. Biol., 7, 13-24, https://doi.org/10.2478/s11535-011-0085-x

Wielbo J., Marek-Kozaczuk M., Kidaj D., and Skorupska A., 2011. Competitiveness of Rhizobium leguminosarum bv. trifolii strains in mixed inoculation of clover (Trifolium pratense). Pol. J. Microbiol., 60, 43-49.

Wielbo J., Marek-Kozaczuk M., Kubik-Komar A., and Skorupska A., 2007. Increased metabolic potential of Rhizobium spp. is associated with bacterial competitiveness. Can. J. Microbiol., 53, 957-967, https://doi.org/10.1139/W07-053

Wielbo J., Marek-Kozaczuk M., Mazur A., Kubik-Komar A., and Skorupska A., 2010. Genetic and metabolic divergence within a Rhizobium leguminosarum bv. trifolii population recovered from clover nodules. Appl. Environ. Microb., 76, 4593-4600, https://doi.org/10.1128/AEM.00667-10

Zahir Z.A., Zafar-ul-Hye M., Sajjad S., and Naveed M., 2011. Comparative effectiveness of Pseudomonas and Serratia sp. containing ACC-deaminase for coinoculation with Rhizobium leguminosarum to improve growth, nodulation, and yield of lentil. Biol. Fert. Soils, 47, 457-465, https://doi. org/10.1007/s00374-011-0551-7

Zantua M.I. and Bremner J.M., 1977. Stability of urease in soils. Soil Biol. Biochem., 9, 135-140, https://doi. org/10.1016/0038-0717(77)90050-5

Zhang N., He X., Gao Y., Li Y., Wang H., Ma D., Zhang R., and Yang S., 2010. Pedogenic carbonate and soil dehydrogenase activity in response to soil organic matter in artemisia ordosica community. Pedosphere, 20, 229-235. 